\title{
ANTIBODY RESPONSE IN CATTLE AFTER VACCINATION WITH INACTIVATED AND ATTENUATED RABIES VACCINES
}

\author{
Andréa de Cássia RODRIGUES da SILVA(1), Graciane Maria Medeiros CAPORALE(1), Celso Alberto GONÇALVES(2), Mosar Couteiro TARGUETA(3), \\ Fabiano COMIN(4), Carlos Roberto ZANETTI(4) \& Ivanete KOTAIT(1)
}

\begin{abstract}
SUMMARY
Despite the absence of current official reports showing the number of cattle infected by rabies, it is estimated that nearly 30,000 bovines are lost each year in Brazil. In order to minimize the important economic losses, control of the disease is achieved by eliminating bat colonies and by herd vaccination. In this study, we compare the antibody response in cattle elicited by vaccination with an attenuated ERA vaccine (AEvac) and an inactivated-adjuvanted PV (IPVvac) vaccine. The antibody titers were appraised by cell-culture neutralization test and ELISA, and the percentage of seropositivity was ascertained for a period of 180 days. IPVvac elicited complete seropositivity rates from day 30 to day 150 , and even on day $180,87 \%$ of the sera showed virus-neutralizing antibody titers (VNA) higher than $0.5 \mathrm{IU} / \mathrm{ml}$. There were no significant differences between the VNA titers and seropositivity rates obtained with IPVvac in the two methods tested. AEvac, however, elicited significantly lower titers than those observed in the group receiving inactivated vaccine. In addition, the profiles of antirabies IgG antibodies, evaluated by ELISA, and VNA, appraised by cellculture neutralization test, were slightly different, when both vaccines were compared.
\end{abstract}

KEYWORDS: Rabies, Cattle vaccination, Neutralizing antibodies, Antirabies IgG.

\section{INTRODUCTION}

Rabies is transmitted to cattle by different animals in different regions of the world. In North America, foxes and skunks transmit the disease to cattle ${ }^{11}$; in Europe it is transmitted by foxes ${ }^{14}$, while in India dogs are the major source of transmission ${ }^{17}$. In Latin America however, the vampire bat (Desmodus rotundus) is mainly responsible for transmitting the disease to livestock ${ }^{11}$. In spite of the fact that this mode of rabies transmission was first reported in 1911 in $\mathrm{Brazil}^{5}$, no official reports showing the exact number of cattle infected by rabies in our country have so far been published. According to unofficial information obtained from the Brazilian Ministry of Agriculture, it is estimated that nearly 30,000 bovines are lost each year in Brazil. In order to minimize the important economic losses, one of the methods for controlling the disease consists of exterminating vampire bat colonies with anticoagulants $\mathrm{s}^{7,13,19}$. Since it is largely non-selective, killing also non-hematophagous bats, this approach has been strongly criticized by conservationist groups. For this reason, at the moment, vaccination seems to be the most suitable measure for the protection of cattle.

Although different studies have demonstrated that Brazilian inactivated vaccines are safer and are at least as efficient as attenuated live virus vaccines ${ }^{8,18}$, the latter are still the most frequently used in many regions of the country, mainly because of the belief that this kind of vaccine affords longer-term immunity than the inactivated type.

The aim of this study was to measure and compare the antibody response elicited by vaccinating cattle with attenuated and inactivated rabies vaccines commercially available in Brazil. An attenuated ERA vaccine (AEvac) and an inactivated-adjuvanted PV vaccine (IPVvac) were tested. Both vaccines were purchased in veterinary stores and applied according to manufactures' specifications. The potency tests were performed by LARA (Reference Animal Laboratory, Campinas, SP, Brazil) following the instructions of the Brazilian Ministry of Agriculture and the World Health Organization (WHO $)^{9,10}$. The seropositivity rates and the antibody titers, appraised by both cell-culture neutralization test and ELISA, were ascertained for a period of 180 days.

\section{MATERIAL AND METHODS}

\section{Animals}

Sixty-four healthy bovines, belonging to three different farms in the State of São Paulo, were divided into 2 groups. Group 1 consisted of 29 young adult animals which were vaccinated with two doses (with an

(1) Seção de Diagnóstico, Instituto Pasteur, São Paulo, SP, Brazil.

(2) Coordenadoria de Defesa Agropecuária, CDA/SAA/SP, Brazil.

(3) Delegacia Federal do Ministério da Agricultura e Abastecimento de São Paulo, SP, Brazil.

(4) Laboratório de Imunologia (MIP/CCB), Universidade Federal de Santa Catarina, Florianópolis, SC, Brazil.

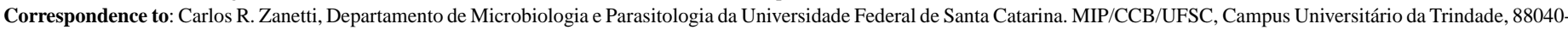
900 Florianópolis, SC, Brazil. Phone: 5548 331-9512. Fax: 5548 331-9258. Email:zanetti@ ccb.ufsc.br 
one-month interval) of $2 \mathrm{ml}$ of IPVvac. Group 2 consisted of 35 young adult animals which received a 2-ml dose of AEvac.

\section{Rabies Vaccines}

The following vaccines were employed:

a) IPVvac: a rabies vaccine prepared with the PV fixed virus grown on BHK-21 cell-line, inactivated by $\beta$ propiolactone, adjuvanted with aluminium hydroxide; approved with a Habel value ${ }^{9}$ of $10^{6,7}$.

b) AEvac: a lyophilised attenuated ERA virus of BHK-21 cell culture origin, (virus titer of $10^{3.83} / 0.03 \mathrm{ml}$ ) approved with $100 \%$ protection in the Koprowski test ${ }^{10}$.

\section{Blood collection}

Blood samples were obtained by jugular puncture before vaccination and also on days 30,60, 90, 120, 150 and 180. Serum samples were prepared, heat-inactivated, batched and stored at $-20^{\circ} \mathrm{C}$.

\section{Determination of virus neutralizing antibody titers (VNA)}

VNA were determined by infection inhibition of BHK-21 (Baby Hamster Kidney) cells as previously described ${ }^{6}$, employing as reference an equine hiperimmune antirabies serum diluted to contain $20 \mathrm{IU} / \mathrm{ml}$. Samples were assayed in duplicate in serial two-fold dilutions, starting with a dilution of 1:5. Data are expressed as International Units/ml (IU/ml).

\section{Elisa Technique}

The immunoassay used was that previously described by PIZA et $a l .{ }^{15}$, with some modifications briefly described here. Disposable flatbottom high-binding ELISA plates were employed and all immunoreagents were assayed in $200 \mu \mathrm{l}$ volumes. Between all steps of the reaction, microplates were washed six times with PBS containing $0.05 \%$ Tween 20. For microplate coating, Human Diploid Cell Culture Vaccine (PasteurMériéux, Marnes la Coquette, France) diluted in 0.05 M sodium carbonate- bicarbonate buffer ( $\mathrm{pH} 9.6$ ), incubated for 1 hour at $37{ }^{\circ} \mathrm{C}$, was used. After incubation, $300 \mu \mathrm{l}$ of blocking buffer (Tris $-\mathrm{NaCl}$ with $0.5 \%$ gelatine) was added to each well, and the plates were incubated for 30 minutes at 37 ${ }^{\circ} \mathrm{C}$. Sera and conjugates (Monoclonal anti-bovine IgG Biotin Conjugate, Sigma B-9780, and Avidin-peroxidase, Sigma A-3151) were diluted in PBS containing $0.5 \%$ gelatine and $0.05 \%$ Tween-20, and were incubated for 1 hour at $37{ }^{\circ} \mathrm{C}$. Thirty minutes after the addition of the substrate/ chromogen (OPD $0.04 \%$ in $0.1 \mathrm{M}$ citrate-phosphate buffer $\mathrm{pH} 5.0$ and $0.03 \% \mathrm{H}_{2} \mathrm{O}_{2}$ ), the enzymatic reaction was halted with $50 \mu$ of $\mathrm{H}_{2} \mathrm{SO}_{4} 4 \mathrm{~N}$. Absorbance was read at $492 \mathrm{~nm}$ using a microplate reader (Titertek Multiskan MCC/340). A checkerboard titration employing the positive and negative reference sera was performed to determine the best antigen protein concentration for coating the microplate and the best dilution of sera and conjugate. The cut-off value was established after calculating the mean $(0.056)$ and the standard deviation $(\mathrm{s}=0.034)$ of 58 negative bovine serum samples. The mean plus $1 \mathrm{~s}$ was considered as the upper limit of negative sera (0.09) with a confidence level of $99 \%$.

\section{RESULTS}

\section{Seropositivity rates and VNA titers}

The titers of rabies antibody found in the serum samples from bovines immunized with the 2 different vaccines tested are shown in Figure 1. Figure 1a presents the virus-neutralizing antibody, obtained by virus neutralization test, and Figure $1 \mathrm{~b}$ shows rabies IgG antibodies, measured by ELISA. The results correspond to collection days 0, 30, 60, 90, 120, 150 and 180. IPVvac elicited significantly higher VNA titers than AEvac $(\mathrm{p}<0.05)$, from day 30 up to day 180, regardless of the test used for antibody titration. ELISA, however, was unable to detect the modest rise in antibody titers elicited by AEvac from day 30 to day 90, detected by the neutralization test.

The seropositivity rates are shown in Figures $2 \mathrm{a}$ and $2 \mathrm{~b}$. Animals receiving IPVvac showed $100 \%$ seropositivity rates from day 30 up to day 150 when calculations were based upon VNA obtained by cell-culture a

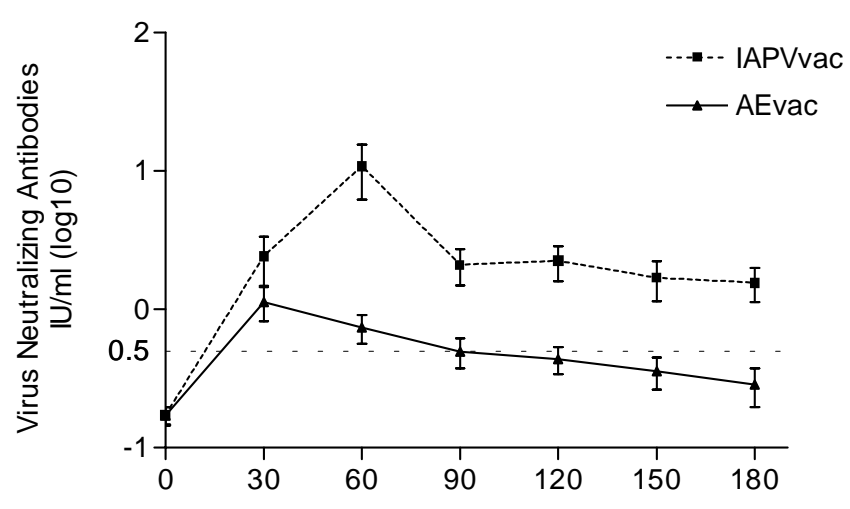

b

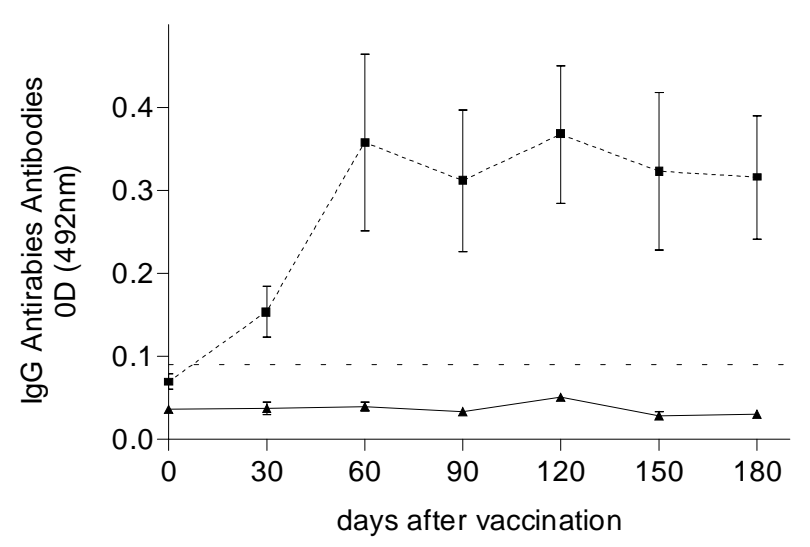

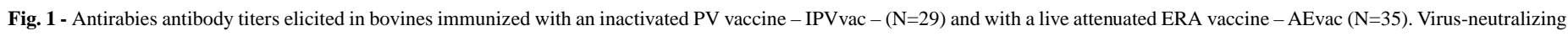

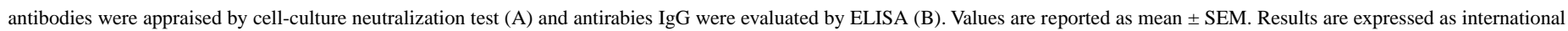
units per $\mathrm{ml}(\mathrm{IU} / \mathrm{ml})$ for the neutralization assay and as optical density (OD) for the enzymatic assay. 

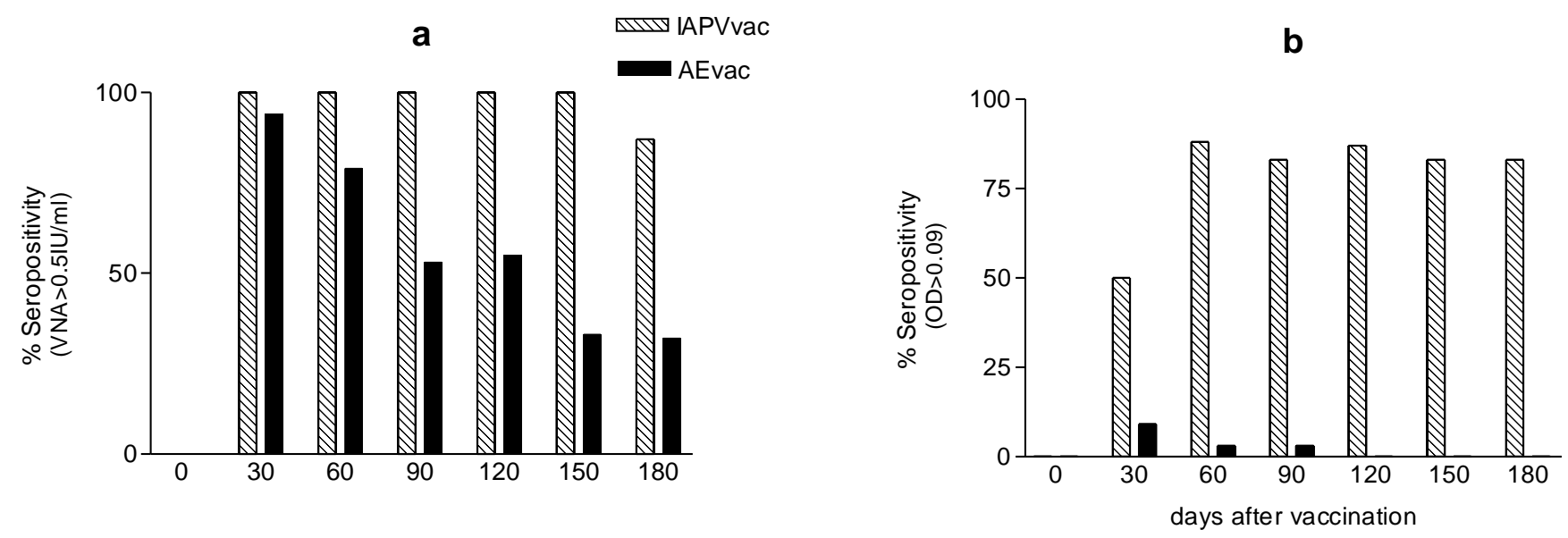

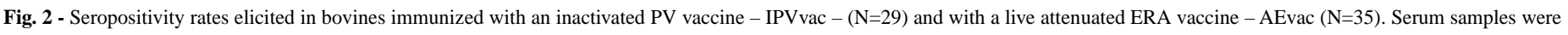
considered as positive when antibody titers were $\geq 0.5 \mathrm{IU} / \mathrm{ml}$ (A) or OD values $\geq 0.09$ (B) for virus-neutralizing test and ELISA, respectively.

neutralization test (Fig. 2a). These results matched those achieved by the immunoassay fairly well (Fig. 2b). When the seropositivity rates elicited by AEvac were calculated based upon ELISA values however, much lower rates were obtained than those observed with IPVvac. Although the AEvac group showed near $100 \%$ seroconversion by day 30 (considering VNA $\geq 0.5 \mathrm{IU} / \mathrm{ml}$ ), the seropositivity rates continuously fell, and by day 150 the seropositivity rate was as low as $33 \%$.

In contrast to the results seen for IPVvac, AE vac seropositivity rates obtained by cell-culture assay were very distinct from those achieved by immunoassay. While $94 \%$ of positivity was achieved according to neutralization test by day 30 , only $9 \%$ of serum samples showed values higher than the cut-off $(\mathrm{OD} \geq 0.09)$ when the seropositivity was calculated based upon the ELISA titers.

\section{DISCUSSION}

Several trials performed in different countries provide sufficient evidence that many vaccines will protect cattle against bovine paralytic rabies ${ }^{11,16,18}$. Nevertheless, the use of attenuated rabies vaccines should be regarded with very special attention in tropical countries such as Brazil. Apart from its handling being much more restrictive due to high temperatures under field conditions, it is also risky since most of the immunization procedure for handling infective virus is not carried out by competent practitioners, being left to the owners themselves. Although there are some reports showing the efficacy of inactivated vaccines ${ }^{8,11,17}$, the frequent use of attenuated vaccines in several regions of Brazil is attributed to the belief that they afford longer-term immunity. The antibody titers and seropositivity rates obtained with the ERA-attenuated vaccine in the present study conflict with this idea. Both parameters were found to be significantly lower than those observed for inactivated vaccine. This might be a consequence of several factors: the ERA vaccine was administered as a single- $2 \mathrm{ml}$ dose, according to the manufactures' instructions, while the PV inactivated vaccine was given in two- $2 \mathrm{ml}$ doses with a one-month interval. Although by day 30 IPVvac had already elicited higher levels of rabies VNA and IgG titers than AEvac, the differences widely increased after the second dose of IPVvac, which confirms the requirement of 2 injections of a live vaccine for the effective immunization of cattle against rabies, previously reported ${ }^{4}$. In addition, the presence of aluminium hydroxide as an adjuvant has been extensively reported as an important immunity enhancer for cattle vaccines ${ }^{11,16,17}$. Another important factor to be considered is the unstable feature of attenuated vaccines, much more subject to immunogenicity loss by temperature shifts than inactivated ones. Considering that the sample used in this study was purchased in a veterinary store, its inappropriate handling cannot be ruled out.

A further point that should be raised is the fact that, because rabies vaccines are officially controlled in Brazil by tests performed on laboratory animals (mice or guinea-pigs), it is always questionable whether the minimal mandatory requirements for a vaccine being approved really correspond to high immunogenicity in the target species. CAMERON et $a l .{ }^{4}$ have shown that five different live rabies vaccines, all conferring at least $80 \%$ protection according to the guinea-pig potency test, evoke extensive variation in antibody titers in bovines, ranging from 4 to $128 \mathrm{IU} / \mathrm{ml}$. We are presently studying the correlation among potencies of rabies vaccines tested by the NIH test ${ }^{20}$, performed on mice, rabies glycoprotein content appraised by ELISA, and virus-neutralizing antibodies induced in bovines, in an attempt to add new details on this matter. In Brazil, the occurence of rabies among bovines supposedly protected by rabies immunization is not uncommon. Besides the factors discussed above, another reason for this is the fact that rabies vaccination is not compulsory for cattle, being frequently a subject of concern by animal owners only when the outbreak has already been established, and therefore accomplishing frustrating results.

Finally, it is important to discuss the differences found between the antibody titers assessed by neutralization test and ELISA. While antibody titers elicited by IPVvac were in complete agreement when appraised either by virus neutralization assay (Fig. 1a) or ELISA (Fig. 1b), the profiles observed for those elicited by AEvac did not coincide. Since neutralization tests do not discriminate immunoglobuline isotypes, we first suspected that the differences were caused by the presence of $\operatorname{IgM}$, which were not detected by the specific anti-bovine $\mathrm{IgG}$ conjugate used in the ELISA. Surprisingly, we were unable to demonstrate the presence of IgM in any serum sample (data not shown). 
RODRIGUES da SILVA, A.C.; CAPORALE, G.M.M.; GONÇALVES, C.A.; TARGUETA, M.C.; COMIN, F.; ZANETTI, C.R. \& KOTAIT, I. - Antibody response in cattle after vaccination with inactivated and attenuated rabies vaccines. Rev. Inst. Med. trop. S. Paulo, 42(2): 95-98, 2000.

A further conceivable explanation is that the use of virus strains for antibody titration different from those found in the vaccines was responsible for bringing about the conflicting results. While rabies virus samples used in the neutralization test and ELISA were respectively PV and PM strains, vaccinal strains were PV and ERA, for IPVvac and AEvac, respectively. Consequently, homology only existed between the vaccinal virus strain and the target strain for those serum samples from bovines immunized with IPVvac when neutralization assay was used for testing. We have recently reported that people receiving PM-cellculture had significantly higher VNA titers when their serum samples were tested against CVS strain than they did when they were tested against PV strain ${ }^{21}$, corroborating this supposition.

In conclusion, our results confirm that inactivated-adjuvanted rabies vaccine can afford high VNA titers and seropositivity rates in bovines ${ }^{3,11,18}$. Although we have not challenged these animals, neutralizing antibody levels is largely accepted as evidence of immunity ${ }^{2,3}$. In addition, we have also shown that the results obtained by different tests may conflict when vaccinal virus strains are not the same as those used in the laboratory assay.

\section{RESUMO}

\section{Resposta imune humoral anti-rábica em bovinos imunizados com vacina inativada e atenuada}

A raiva bovina, transmitida principalmente pelo morcego hematófago Desmodus rotundus, é endêmica em várias regiões do Brasil, com um crescente número de casos sendo registrados anualmente. $\mathrm{O}$ controle desta infecção em bovinos é feito pelo controle de colônias de morcegos hematófagos e pela vacinação dos rebanhos. Embora as vacinas inativadas sejam mais seguras e mais estáveis que as vacinas atenuadas, estas últimas são ainda amplamente utilizadas em muitas regiões do país, por se acreditar que confiram imunidade mais duradoura. Neste estudo, foram comparadas as respostas anticórpicas de dois grupos de bovinos imunizados com uma vacina atenuada e uma inativada disponíveis comercialmente. Os anticorpos anti-rábicos neutralizantes $(\mathrm{AcN})$ foram titulados pela técnica de soroneutralização em cultura de células BHK21, enquanto que os níveis de anticorpos anti-rábicos totais (IgG) foram avaliados pela técnica de ELISA, por um período de 180 dias. A vacina inativada induziu a soroconversão $(\mathrm{AcN} \geq 0,5 \mathrm{UI} / \mathrm{ml}) \mathrm{em} 100 \%$ dos animais no dia 30 , mantendo-se assim até o $150^{\circ}$ dia; no dia $180,87 \%$ dos animais ainda mostravam-se com títulos de $\mathrm{AcN} \geq 0,5 \mathrm{UI} / \mathrm{ml}$. Neste grupo, os níveis de IgG anti-rábicas foram semelhantes aos de AcN. A vacina atenuada, no entanto, induziu títulos de $\mathrm{AcN}$ e de IgG significantemente menores que os encontrados com a vacina inativada, com consequente diminuição da taxa de soropositividade. Além disso, ao contrário do verificado com a vacina inativada, o perfil de AcN não teve paralelismo com o de anticorpos IgG quando soros foram testados pela técnica de soroneutralização e pelo ELISA, respectivamente.

\section{ACKNOWLEDGEMENTS}

Fabiano Comin is a scientific initiation fellowship holder of the Conselho Nacional de Desenvolvimento Científico e Tecnológico-CNPq.

\section{REFERENCES}

1. ARELLANO-SOTA, C. - Vampire bat-transmitted rabies in cattle. Rev. infect. Dis., 10: S707-S709, 1988.
2. BAER, G.M. - Serum neutralizing antibody after rabies post-exposure prophylaxis. In: BAER, G.M. The natural history of rabies. New York, Academic Press, 1975. v. 2, p. 387 .

3. BALTAZAR, R.S. \& BLANCOU, J. - Evaluación de la inmunidad conferida en bovinos por una vacuna antirrábica producida en cultivo celular a partir de virus inactivados. Vet. Méx., 18: 207-213, 1987

4. CAMERON, C.M.; BARNARD, B.J.H.; ERASMUS, E. \& BOTHA, W.J.S. - Antibody response in cattle to oil emulsion rabies and ephemeral fever vaccines. Onderstepoort J. vet. Res., 54: 157-158, 1987.

5. CARINI, A. - Sur une grande epizootie de rage. Ann. Inst. Pasteur, 25: 843-846, 1911

6. FAVORETTO, S.R.; CARRIERI, M.L.; TINO, M.S.; ZANETTI, C.R. \& PEREIRA, O.A.C. - Simplified fluorescent inhibition microtest for the titration of rabies neutralizing antibodies. Rev. Inst. Med. trop. S. Paulo, 35: 171-175, 1993.

7. FLORES CRESPO, R.; FERNANDEZ, S.S.; DE ANDA LÓPEZ, D.; IBARRA VELARDE, F. \& ANAYA D.G., R.M. - Nueva técnica para el combate de los vampiros: Warfarina por vía intramuscular al ganado bovino. Bol. Ofic. sanit. panamer., 87: 283-299, 1979.

8. GUIDOLIN, R.; BALTAZAR, M.C. \& ZELANTE, F. - Produção da vacina anti-rábica veterinária em suspensão de células BHK. Rev. Microbiol. (S. Paulo), 14: 27-35, 1983.

9. HABEL, K. - Habel test for potency. In: MESLIN, F.X.; KAPLAN, M.M. \& KOPROWSKI, H., ed. Laboratory techniques in rabies. 4.ed. Geneva, WHO, 1996. p. $369-373$.

10. KOPROWSKI, H. - Guinea-pig potency test for chicken-embryo vaccine. In: MESLIN, F.X.; KAPLAN, M.M. \& KOPROWSKI, H., ed. Laboratory techniques in rabies. 4.ed. Geneva, WHO, 1996. p. 374-377.

11. LARGHI, O.P. \& NEBEL, A.E. - Duration of immunity afforded to cattle by a binaryethylenimine inactivated rabies vaccine. Zbl. Vet.-Med. B., 32: 609-615, 1985.

12. LINHART, S.B. - The biology and control of vampire bats. In: BAER, G.M. The natural history of rabies. New York, Academic Press, 1975. v. 2, p. 221-241.

13. LINHART, S.B.; FLORES CRESPO, R. \& MITCHELL, G.C. - Control de murciélagos vampiros por medio de un anticoagulante. Bol. Ofic. sanit. panamer., 73: 100-109, 1972.

14. PÉPIN, M.; BLANCOU, J. \& AUBERT, M.F.A. - Rage expérimentale des bovins: sensibilité, symptômes, réactions immunitaires humorales, lésions et excrétion du virus. Ann. Rech. vét., 15: 325-333, 1984.

15. PIZA, A.S.T.; SANTOS, J.L.F.; CHAVES, L.B. \& ZANETTI, C.R. - An ELISA suitable for detection of rabies virus antibodies in serum samples from human vaccinated with either cell-culture vaccine or suckling-mouse brain vaccine. Rev. Inst. Med. trop. S. Paulo, 41: 39-43, 1999.

16. PROSPERI, A.; IRSARA, A.; BATTELLI, G. \& SANGUINETTI, V. - Vaccination of cattle with live and inactivated rabies vaccines: a study of antibody response. Vet. Res. Commun., 8: 181-185, 1984.

17. RAMANNA, B.C. \& SRINIVASAN, V.A. - Serological response in cattle to tissue culture rabies vaccine. Indian. vet. J., 69: 11-13, 1992.

18. RIBEIRO NETO, A.; NILSSON, M.R.; CORTÊS, J.A.; MIZUMO, M. \& MIGUEL, O. - Comparative study of cattle antirabies vaccines. II. Protection conferred by Alurabifa, ERA and Formidogel vaccines. Zbl. Vet.-Med. B., 20: 378-404, 1973.

19. THOMPSON, R.D.; MITCHELL, G.C. \& BURNS, R.J. - Vampire bat control by systemic treatment of livestock with an anticoagulant. Science, 177: 806, 1972.

20. WILBUR, L.A. \& AUBERT, M.F.A. - The NIH test for potency. In: MESLIN, F.X.; KAPLAN, M.M. \& KOPROWSKI, H., ed. Laboratory techniques in rabies. 4.ed. Geneva, WHO, 1996. p. 360-368.

21. ZANETTI, C.R.; CONSALES, C.A.; RODRIGUES DA SILVA, A.C.; TOYOSHIMA, Y.K. \& PEREIRA, O.A.P. - Short duration of neutralizing antibody titers after preexposure rabies vaccination with suckling mouse brain vaccine. Braz. J. med. biol. Res., 31: 1275-1280, 1998.

Received: 13 October 1999

Accepted: 27 December 1999 